\title{
Leucocoprinus brebissonii (Godey) Locq, A New Record for Turkish Mycobiota
}

\author{
Ali KELEŞ*, Yılmaz ORUÇ \\ Yüzüncü Yll University, Education Faculty, Department of Science and Mathematics Education, Van, Turkey \\ *alikeles61@yahoo.com
}

\section{Leucocoprinus brebissonii (Godey) Locq, Türkiye Mikobiyotası için Yeni Bir Kayit}

\begin{abstract}
The genus Leucocoprinus Pat. is situated in the order Agaricales within the phylum Basidiomycota. Though the genus comprises about 40 species worlwide, it is among the genera which are represented with the least taxa in Turkey. About 2400 macrofungi taxa have been determined as a result of the studies carried out in Turkey till now. This number is very low compared to European continent. That's why it is important to determine the macrofungal diversity of Turkey by continuing such studies. In Turkey, Leucocoprinus brebissonii (Godey) Locq was determined for the first time from Sürmene (Trabzon). Macroscopic and microscopic properties of the taxon was provided and discussed briefly.
\end{abstract}

Key words: Biodiversity, Leucocoprinus, new record, Trabzon, Turkey

Özet: Leucocoprinus Pat. cinsi, Basidiomycota bölümünün Agaricales ordosu içerisinde yer alır. Cins dünya genelinde yaklaşık 40 tür ile temsil edilmesine rağmen, Türkiye'de en az türle temsil edilen cinsler arasında yer almaktadır. Türkiye'de şu ana kadar gerçekleştirilen çalışmalar sonucunda yaklaşık 2400 makromantar taksonu belirlenmiştir. Bu sayı Avrupa kıtası ile kıyaslandığında oldukça azdır. Bu nedenle bu gibi çalışmalar sürdürülerek Türkiye'nin makromantar çeşitliliğinin ortaya konması önem arz etmektedir. Leucocoprinus brebissonii (Godey) Locq türü Türkiye'de ilk kez bu çalısma ile Sürmene (Trabzon)'den tespit edilmiştir.Türün makroskobik ve mikroskobik özellikleri verilerek kısaca tartışılmıştır.

Anahtar Kelimeler: Biyoçeşitlilik, Leисосорrinus, yeni kayıt, Trabzon, Turkiye

\section{Introduction}

Turkey has a diverse plant cover due to its geographical position. Depending on this diversity, it is thought that the country might also have a similar macrofungal diversity. It is also the estimate of Mueller et al. (2007) regarding the plant/macrofungus ratios of temperate regions. Due to its climate and plant cover, Black Sea region is among the richest region of Turkey in terms of macrofungal diversity.

Though there is an important increase in the number of studies carried on the macrofungal diversity, the mycobiota of Turkey has not been completed yet. With such studies, the determined macrofungi species number of our country is being increased.

The last checklists about the determined macrofungi lists of Turkey were presented by Sesli and Denchev (2014), and Solak et al. (2015) in 2014 and 2015 respectively. Since mycodiversity studies are going on in an increasing manner, many contributions (Uzun et al., 2015; Acar and Uzun, 2016; Öztürk et al., 2016; Taşkın et al., 2016; Öztürk et al., 2017) were also made to these checklist.

During a field study in Sürmene district of Trabzon province, some white coprinoid fungi samples were collected. As a result of necessary investigation, they were identifed as Leucocoprinus brebissonii (Godey) Locq. The current checklists (Sesli and Denchev, 2014; Solak et al., 2015) and the contributions which were made after the checklist (Acar et al., 2015; Akata et al., 2016; Demirel et al., 2016; Dengiz and Demirel, 2016; Kaya, 2016; Aktaş et al., 2017; Demirel et al., 2017; Işık and Türkekul, 2017; Sesli and Sesli, 2017; Sesli and Vizzini 2017; Uzun and Demirel, 2017; Uzun and Kaya, 2017; Uzun et al., 2017a; 2017b) were checked and it is found that the taxon has not been reported from Turkey.

The aim of this study is to make a contribution to the mycobiota of Turkey.

\section{Materials and Method}

Macrofungi samples were collected from Sürmene district of Trabzon Province in 2014 during a routine field study. Colour photographs of the samples were taken and some ecologic and morphologic properties of the samples were recorded. After that the macrofungi samples were brought to the fungarium and prepared as fungarium materials according to mycological rules. Dried samples were used to obtain the microscopic data. Microscopic investigations were carried out under a light microscope by mounting in $5 \% \mathrm{KOH}$. Basidispore dimensions were determined by at least 10 measurement from each sample.

The macrofungi samples were identified with the help of Moser (1983), Buczacki (1989), Breitenbach and Kränzlin (1995), Rother and Silveira (2009) and Pushpa and Purushothama (2011). They are protected at Yüzüncü Y1l University Fungarium (VANF).

\section{Results}

The systematic of the taxon is given in accordance with Kirk et al. (2008), and the Index Fungorum (www.indexfungorum.org; accessed 25 October 2017).

\section{Fungi Bartling}

Basidiomycota R.T. Moore

Agaricales Underw.

Agaricaceae Chevall. 
Leucocoprinus brebissonii (Godey) Locq., Bull. mens. Soc. linn. Soc. Bot. Lyon 12: 95 (1943)

Syn: Lepiota brebissonii Godey, Lepiota cepistipes var. cretacea Grev.

Macroscopic and microscopic features: Pileus 2-4 cm in diameter, ovoid to conic-campanulate when young, convex to plane when mature, slighthly umbonate, surface white, covered by greenish brown to blackish-brown squamulous fibrils at the center, paler to white toward the margin, plicate sulcate to striate at the margin or half-way toward the disk in some members. Flesh thin up to $1 \mathrm{~mm}$ and white. Lamellae free, white. Stipe $30-60$ x 2-3 mm, cylindric, slighthly bulbous at the base, solid when young, becoming hollow at maturity, surface white, pruinose, annulus membranous, persistent, white, attached half-way zone of the stipe.

Basidia 25-30 x 6-11 $\mu \mathrm{m}$, clavate with four sterigmata, Cheilocystidia 27-40 × 12-14 $\mu \mathrm{m}$, cylindric to clavate, hyaline, Spores 9-13 x 6-8 $\mu \mathrm{m}$, ellipsoid, truncated by an apical germ-pore, hyaline, thick walled.

Ecology: Leucocoprinus brebissonii grows on soil among leaf litter or on leaf litter, in hardwood forests, parks and greenhouses (Breitenbach and Kränzlin, 1995; Rother and Silveira, 2009; Pushpa and Purushothama, 2011).

Specimen examined: Trabzon, Sürmene, Çamburnu $40^{\circ} 12^{\prime} 740 " \mathrm{E}, 70 \mathrm{~m}, 14.09 .2014$, O.003. village, mixed forest clearing, meadow, 40 $55^{\prime} 362^{\prime \prime} \mathrm{N}$,

\section{Discussions}

Leucocoprinus brebissonii is characterized by having white pileus, covered with dark-brown fibrils at the disk, plicate-striate margin, white spore-print, thick walled and metachromatic basidiospores with a distinct germ pore (Candusso and Lanzoni 1990; Breitenbach and Kränzlin, 1995; Rother and Silveira, 2009; Pushpa and Purushothama, 2011). Our sample fits with all the characters listed above. This taxon is differentiated from the other similar species with above listed characteristics (Candusso and Lanzoni, 1990). The metachromatic spores, absence of clamps, and the striate pileus also distinguishes it from some other similar species such as Lepiota cristata and L. felina.

Like other Leucocoprinus species, L. brebissonii have also been recorded from greenhouses, but this one can also fruits in nature freely, especially in warm locations.

Leucocoprinus brebissonii have morphological similarities with $L$. venezuelanus Dennis. But the latter species differs with smaller basidiospores.

In conclusion Leucocoprinus brebissonii was added as new record to the mycobiota of Turkey, increasing the number of current members of the genus Leucocoprinus from 5 to 6 .

\section{Acknowledgements}

The study was supported by Yüzüncü Y1l University Research Fund (2015-FBE-YL 108).

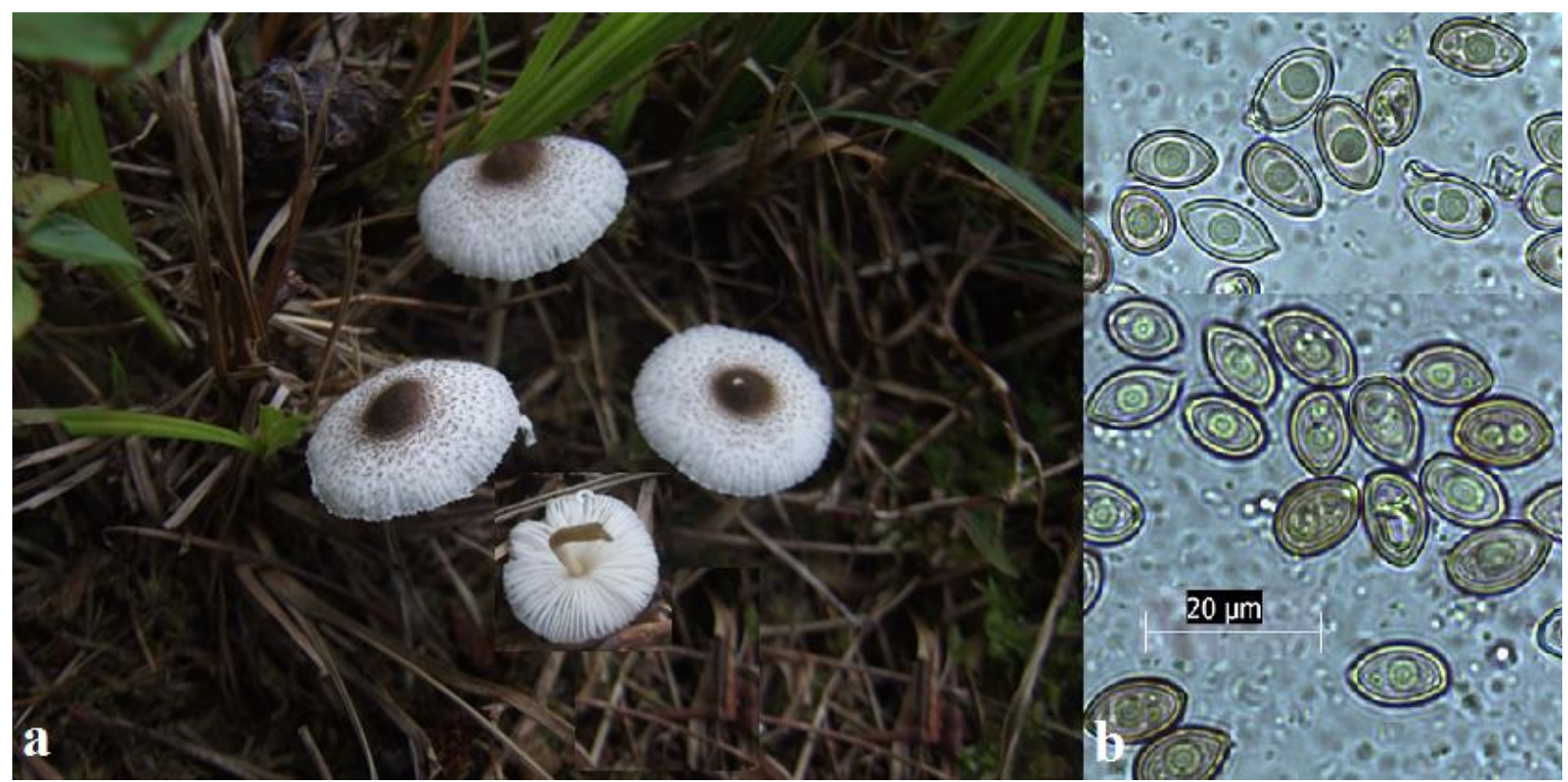

Figure 1. Basidiocarps (a) and basidiospores (b) of Leucocoprinus brebissonii

\section{References}

Acar İ, Uzun Y (2016). Peziza granularis Donadini Türkiye Mikobiyotası için Yeni Bir Kayıt. Yüzüncü Yı1 University Journal of The Institute of Natural \& Applied Sciences, 21(1):39-42.

Acar İ, Uzun Y, Demirel K, Keleş A (2015). Macrofungal diversity of Hani (Diyarbakır/Turkey) district. Biological Diversity and Conservation, 8(1): 28-34.

Akata I, Uzun Y, Kaya A (2016). Macrofungal diversity of Zigana Mountain (Gümüşhane/Turkey). Biological Diversity and Conservation 9(2): 57-69.

Aktaş S, Öztürk C, Pamukçu D (2017). Nallıhan (Ankara) İlçesi Makrofungusları. The Journal of Fungus 8(1): 60-67. 
Breitenbach J, Kränzlin F (1995). Fungi of Switzerland. Vol. 4, Verlag Mykologia Lucerne, Switzerland.

Buczacki S (1989). Fungi of Britain and Europe. William Collins Sons \& Co Ltd. Glasgow.

Candusso M, Lanzoni G (1990). Lepiota, Fungi Europei 4. Saronno, Giovanna Biella.

Demirel K, Acar İ, Ömeroğlu Boztepe G (2016). Lice (Diyarbakır) Yöresi Makrofungusları. Mantar Dergisi, 7(1): 29-39.

Demirel K, Uzun Y, Keleş A, Akçay ME, Acar İ (2017). Macrofungi of Karagöl-Sahara National Park (ŞavşatArtvin/Turkey). Biological Diversity and Conservation. 10/2: 32-40.

Denğiz Y, Demirel K (2016). Şirvan (Siirt) Yöresinde Yetişen Makrofunguslar Üzerinde Taksonomik Bir Araştırma. Yüzüncü Yıl University Journal of the Institute of Natural \& Applied Sciences 21(2): 112-123.

Index Fungorum (2017). http://www.indexfungorum.org/Names/Names.asp. Accessed 25 October 2017.

Işık H, Türkekul İ (2017). A new record for Turkish mycota from Akdağmadeni (Yozgat) province: Russula decolorans (Fr.) Fr. Epicr.. Anatolian Journal of Botany 1(1): 1-3.

Kaya A (2016). Contributions to the macrofungal diversity of Atatürk Dam Lake basin. Turkish Journal of Botany 39(1): $162-172$.

Kirk PM, Cannon PF, Minter DW, Stalpers JA (2008). Dictionary of the Fungi. 10th ed. Wallingford, UK: CAB International.

Moser M (1983). Keys to Agarics and Boleti. Gustav Fiscer Verlag, Stuttart.

Mueller GM, Schmit JP, Leacock PR, Buyck B, Cifuentes J, Desjardin DE, Halling RE, Hjortstam K, Iturriaga T, Larss on K-H, Lodge DJ, May TW, Minter D, Rajchenberg M, Redhead SA, Ryvarden L, Trappe JM, Walting R, Wu Q (2007). Global diversity and distribution of macrofungi. Biodivers Conserv 16:37-48.

Öztürk C, Pamukçu D, Aktaş S (2017). Nallıhan (Ankara) İlçesi Makrofungusları. The Journal of Fungus 8(2): 60-67.

Öztürk Ö, Doğan HH, Şanda MA (2016). Some new additions to Turkish mycobiota from Sakarya region. Biological Diversity and Conservation 9(1): 97-100.

Pushpa H, Purushothama KB (2011). Leucocoprinus Pat. (Agaricaceae, Agaricales, Basidiomycota) in Bengaluru, Karnataka State, India. World Applied Sciences Jownal14(3): 470-475.

Rother MS, Silveira RMB (2009). Leucocoprinus Pat. (Agaricaceae, Basidiomycota) no Parque Estadual de Itapuã, Viamão, RS,Brasil. Acta Bot. Bras. 23(3): 720-728.

Sesli E, Denchev CM (2014). Checklists of the myxomycetes, larger ascomycetes, and larger basidiomycetes in Turkey. 6th edn. Mycotaxon Checklists Online. (http://www.mycotaxon.com/resources/checklists/sesli-v106-checklist.pdf): $1-136$.

Sesli E, Topcu Sesli A (2017). Infundibulicybe alkaliviolascens (Tricholomataceae): Türkiye Mikotası için Yeni Bir Kayıt. Mantar Dergisi 8(1): 6-12.

Sesli E, Vizzini A (2017). Two new Rhodocybe species (sect. Rufobrunnea, Entolomataceae) from the East Black Sea coast of Turkey. Turkish Journal of Botany 41: 200-210.

Solak MH, Işıloğlu M, Kalmış E, Allı H (2015). Macrofungi of Turkey, Checklist, Vol. II. İzmir, Turkey: Üniversiteliler Ofset (in Turkish).

Taşkın H, Doğan HH, Büyükalaca S, Clowez P, Moreau PA, O’Donnell K (2016). Four new morel (Morchella) species in the elata subclade (M. sect. Distantes) from Turkey. Mycotaxon 131(2): 467-482.

Uzun Y, Acar I, Akçay ME, Kaya A (2017a). Contributions to the macrofungi of Bingöl, Turkey. Turkish Journal of Botany 41(5): 516-534.

Uzun Y, Demirel K (2017). A New Mycena Record for the Mycobiota of Turkey. Anatolian Journal of Botany 1(1,2): 911.

Uzun Y, Kaya A (2017). A Hypogeous Lactarius sp., New to Turkish Mycobiota. The Journal of Fungus 8(2): 163-167.

Uzun Y, Kaya A, Karacan İH, Kaya ÖF, Yakar S (2015). Macromycetes determined in Islahiye (Gaziantep/Turkey) district. Biological Diversity and Conservation 8(3): 209-217.

Uzun Y, Kaya A, Karacan İH, Yakar S (2017b). New additions to Turkish Agaricales. Biological Diversity and Conservation 10(2): 8-13.

Cite this article: Keleş A, Oruç Y (2017). Leucocoprinus brebissonii (Godey) Locq, A New Record for Turkish Mycobiotab Anatolian Journal of Botany 1(2): 49-51. 